\title{
Setting up a French national flash flood warning system for ungauged catchments based on the AIGA method
}

\author{
Pierre JAVELLE ${ }^{1, a}$, Didier ORGANDE ${ }^{2}$, Julie DEMARGNE ${ }^{2}$, Clotilde SAINT-MARTIN ${ }^{1}$, Céline de SAINT-AUBIN ${ }^{3}$, \\ Léa GARANDEAU ${ }^{3}$ and Bruno JANET $^{3}$ \\ ${ }^{1}$ Irstea, RECOVER, CS 40061, 13182 Aix-en-Provence Cedex 5, France \\ ${ }^{2}$ HYDRIS Hydrologie, 5 avenue du Grand Chêne, Saint Mathieu de Tréviers, France \\ ${ }^{3}$ Ministère de l'environnement, de l'énergie et de la mer, DGPR/SRNH/SCHAPI, 42, avenue Gaspard Coriolis, 31057 TOULOUSE \\ Cedex 01, France
}

\begin{abstract}
Occurring at small temporal and spatial scales, flash floods (FF) can cause severe economic damages and human losses. To better anticipate such events and mitigate their impacts, the French Ministry in charge of Ecology has decided to set up a national FF warning system over the French territory. This automated system will be run by the SCHAPI, the French national service in charge of flood forecasting, providing warnings for fast-responding ungauged catchments (area ranging from $\sim 10$ to $\sim 1000 \mathrm{~km}^{2}$ ). It will therefore be complementary to the SCHAPI's national "vigilance" system which concerns only gauged catchments. The FF warning system to be implemented in 2017 will be based on a discharge-threshold flood warning method called AIGA (Javelle et al. 2014). This method has been experimented in real time in the south of France in the RHYTMME project (http://rhytmme.irstea.fr). It consists in comparing discharges generated by a simple conceptual hourly hydrologic model run at a $1-\mathrm{km}^{2}$ resolution to reference flood quantiles of different (e.g., 2-, 10- and 50-year) return periods. Therefore the system characterizes in real time the severity of ongoing events by the range of the return period estimated by AIGA at any point along the river network. The hydrologic model ingests operational rainfall radar-gauge products from Météo-France and takes into account the baseflow and the initial soil humidity conditions to better estimate the basin response to rainfall inputs. To meet the requirements of the future FF warning system, the AIGA method has been extended to the whole French territory (except Corsica and overseas French territories). The calibration, regionalization and validation procedures of the hydrologic model were carried out using data for $~ 700$ hydrometric stations from the 2002-2015 period. Performance of the warning system was evaluated with various contingency criteria (e.g., probability of detection and success rate). Furthermore, specific flood events were analysed in more details, by comparing warnings issued for exceeding different critical flood quantiles and their associated timing with field observations. The performance results show that the proposed FF warning system is useful, especially for ungauged sites. The analysis also points out the need to account for the uncertainties in the precipitation inputs and the hydrological modelling, as well as include precipitation forecasts to improve the effective warning lead time.
\end{abstract}

\footnotetext{
a Corresponding author: pierre.javelle@irstea.fr
} 


\section{Introduction}

\section{Context}

Flash floods are typically caused by extreme rainfall events, which are highly localised and evolving rapidly [1]. Depending on catchment factors such as soil permeability and slope, the hydrological response can be very fast, occurring on time scales ranging from minutes to a few hours [2]. The rapid rising of waters can lead to devastating economic and human losses. Consequently, setting up early warning systems to warn communities and activate appropriate emergency procedures is a crucial and still on-going issue. For instance, in France, the June 15-16, 2010 event in the Var region in the southeast (25 casualties [3]), has emphasized the limits of the official warnings during this event, based on a large-scale weather watch [4]. Following this event, the French ministry of environment has decided, among other measures, to develop an automated warnings system taking into account hydrological responses of the unmonitored streamflows submitted to intense rainfall [5]. The envisioned flash flood warning system will complement the current "flood vigilance" system which is available only on the French monitored river network.

\section{Limits of the river flow forecasting systems}

Similarly to other conventional river flow forecasting systems (RFFS), the current French flood vigilance system is not suitable to efficiently forecast flash flooding. Indeed, as mentioned by [6], RFFS are usually defined to forecast slower events, on greater catchments, taking advantage of all hydro-meteorological monitoring networks (rain gauges, radar and satellite rainfall data, river gauges), locally calibrated hydrological models, and weather forecasts from numerical weather prediction (NWP) models. Such an approach is of limited interest for a flash flood warning systems [2]. First, all catchments prone to flash floods cannot be directly monitored with rain and water levels gauges. Consequently, hydrological models can neither be locally calibrated, nor benefit from river flow data assimilation at the point of interest. Secondly, correctly forecasting convective cells responsible for flash floods is still challenging for NWP models, due to the very small space-time scales of these events, leading to large forecast uncertainties.

Despite these difficulties, important advances have been recently made: rainfall estimations combining weather radars and satellite measurements, nowcasting products for improved very short term precipitation forecasts, probabilistic NWP forecasts to capture and potentially reduce forecast uncertainties, and hydrological modelling. The challenges of ungauged catchments have been effectively addressed by the scientific and operational community in the Predictions in Ungauged Basin (PUB) framework. Promising perspectives have been demonstrated by distributed hydrological modelling approaches, such as the Distributed Hydrologic Model Threshold frequency (DHM-TF, [7]) developed in the United States, the Grid-to-Grid (G2G, [8]) model used in the United-Kingdom, the LISFLOOD model initially developed for large European basins, but successfully adapted for small catchments prone to flash flooding [9] [10], and the CVN and MARINE models which were successfully tested on the Gard 2002 flash flood event in France [11].

\section{Current Flash flood warning systems}

Despite the recent advances made in hydrological modelling, most existing operational flash flood warning systems use simpler approaches based on rainfall threshold methods, which can be more easily interpreted by non-technical stakeholders: warnings are issued when local rainfall cumulated over a determined duration (i.e. 6 hours) and a given area exceeds some specific threshold. These thresholds are usually determined based on experience from past events. To enhance this basic approach, one can determine different threshold values depending on the initial soil moisture condition, since the more saturated the catchment, the lower the rainfall threshold. Furthermore, the Flash Flood Guidance (FFG) approach , widely used operationally in the United States [12] [13], consists in running a hydrological model in inverse mode to determine the amount of rainfall needed to exceed a predefined specific discharge (usually corresponding to a given return period). In Europe, since 2009, the operational European Flood Awareness System (EFAS) produces flash flood warnings based on the European Precipitation Index (EPIC) (www.efas.eu). This index is calculated using COSMO-LEPS ensemble weather forecasts: predicted rainfall is summed over the upstream area and for different durations (i.e. 6, 12 and $24 \mathrm{~h}$ ), and cumulated values are then compared to annual maximal quantiles derived from 20 years of COSMO climatology [14] [15] [16]. Recently, EPIC has been replaced by the European Runoff Index based on Climatology (ERIC) in order to take into account initial soil moisture conditions[17].

\section{The AIGA method}

The flash flood warning system to be implemented in France by the SCHAPI (French national service in charge of flood forecasting) is based on a discharge-threshold flood warning method called AIGA [18]. The AIGA method has been initially developed for the South of France by Irstea and Meteo-France [19]. It has been tested in real time over the last 5 years, with end-users from the "Provence, Alps, French Riviera" region in the framework of the RHYTMME project (http://rhytmme.irstea.fr). It consists in comparing discharges generated by a simple conceptual hourly hydrologic model run based on radar rainfall estimations, to reference flood quantiles of different return periods, at any point along the river network.

The scope of this paper is to present the enhancements of the AIGA method for its integration into the future national warning system. First the enhanced hydrological model is presented. Then, performances are evaluated in two different ways: at gauging stations, as well as ungauged locations, using damage reports of two case studies. Finally, some concluding remarks are drawn. 


\section{The National AIGA method}

\subsection{Model presentation}

The hydrological model running into the AIGA method is based on simple concepts developed over the last 30 years at Irstea, within the GR (Génie Rural Agricultural Engineering) models family. The initial version of the AIGA method is described by [18]. It combines two distributed modules: one continuous model running at a daily time step on $1-\mathrm{km}^{2}$ grids and representing soil moisture conditions (SAJ) and an eventbased module running at an hourly time step, which uses outputs from SAJ as initial humidity states (Fig. 1). In the initial version implemented for Mediterranean catchments, initial flows were assumed to be negligible in comparison with the high flows to be modelled. However this simplification is not acceptable anymore for catchments under other climatic conditions, with potentially significant baseflows.

Therefore, in the national AIGA version presented in this paper, a third module has been included in order to include baseflow estimates in the event-based model. In this third module, the global daily continuous GR4J model (see for instance [20]) calculates daily flows at each target basin outlet covered by AIGA. These daily flows are then used to initialise the routing store of the hourly event-based model (Fig. 1).
In real time, the production and routing stores of the event-based model are initialised every day at 6AM, except if a rainfall event is ongoing. From a practical point of view, at 7AM, if the amount of catchment rainfall cumulated over the last 24 hours exceeds $10 \mathrm{~mm}$, the production and routing stores are not initialised to let the model simulate flows with its internal model states. Furthermore, in order to have up-dated results every 15 minutes, four chains of hourly models are running on the same time, with simply a shifting delay of 15 minutes.

\subsection{Values for parameters and reference flood quantiles}

\section{Models parameters}

The three hydrological models used for the national version of AIGA use the following parameters (Fig. 1):

- $\quad \boldsymbol{A}$ the size of the production stores for the SAJ and GRSD modules (one value per pixel, same value for the two modules);

- $\quad \boldsymbol{B}$ the size of the global routing store of the GRSD model (one value per target catchment);

- $\quad X 1, X 2, X 3$ and $X 4$ the four parameters of the GR4J model (one parameter set per target catchment).

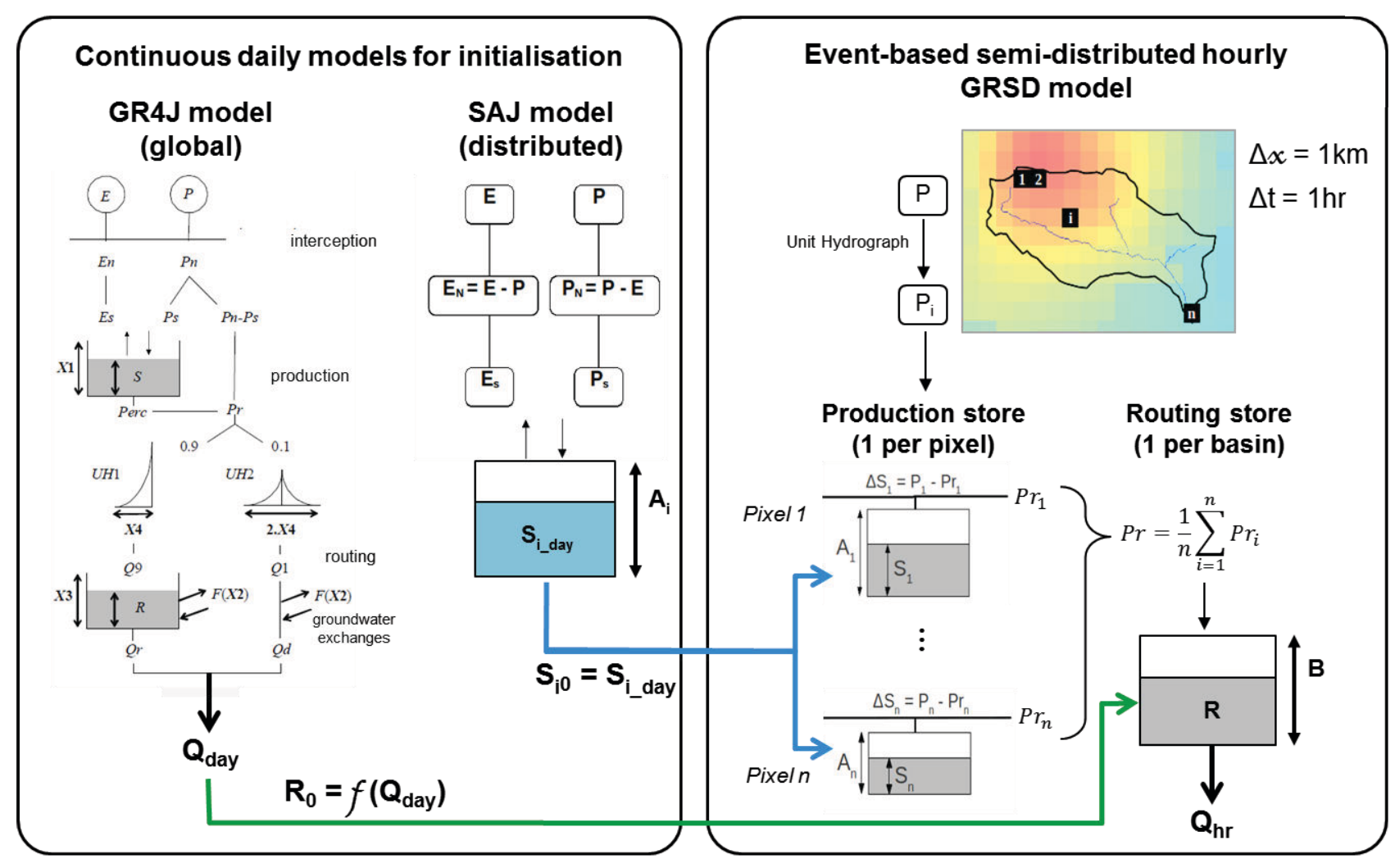

Figure 1. Hydrological model description for the national version of AIGA, with precipitation (P) and evapotranspiration (E) as inputs, and daily and hourly streamflows $\left(\mathrm{Q}_{\mathrm{day}}\right.$ and $\left.\mathrm{Q}_{\mathrm{hr}}\right)$ as outputs 


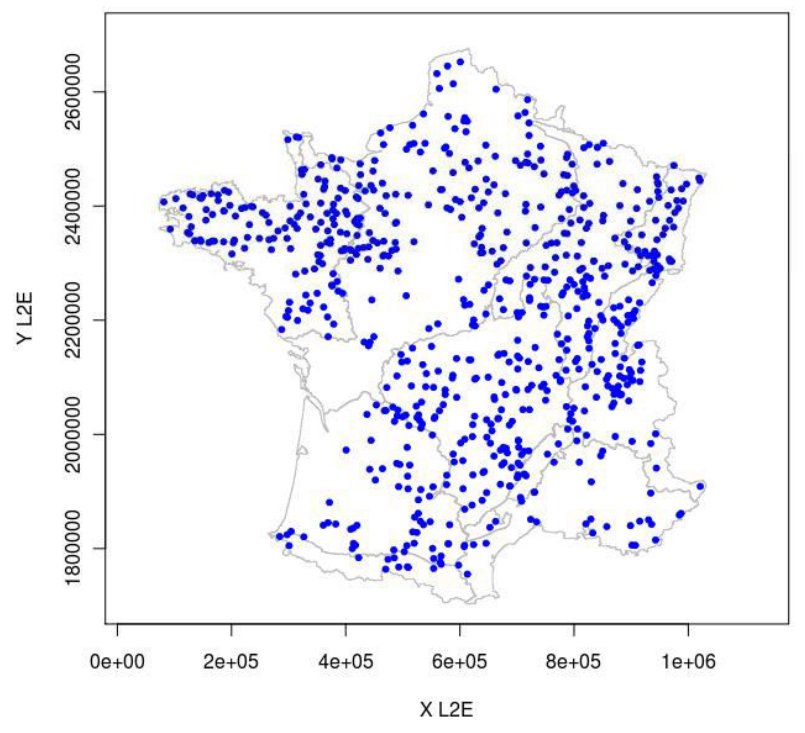

Figure 2. Selected river streamflow stations

Model parameters were calibrated using streamflow measurements of 700 hydrological stations (Fig. 2) from the French national hydrometric database (HYDRO) provided by the SCHAPI and rainfall data provided by Meteo-France. Two available gridded products combining radar and rain gauges data were used: the COMEPHORE re-analysis from 2002 to 2006, and the ANTILOPE product from 2006 to 2015 , in order to obtain rainfall information(at a $1-\mathrm{km}^{2}$ and hourly resolution) from 2002 to 2015.

Since the AIGA method is applied on ungauged catchments, model parameters have to be regionalised to determine parameter sets at each ungauged target. After different jack-knife cross-validation tests (considering each gauged catchment as if it was ungauged), and taking into account the need for the warning system to avoid missing flood events, the best results were obtained with the following parametrisation:

- $\quad \boldsymbol{A}$ uniformly fixed at $200 \mathrm{~mm}$;

- $\quad \boldsymbol{B}$ fixed at 50mm whatever the target catchment to favour a fast hydrological response to precipitation input;

- $X 1, X 2, X 3$ and $X 4$ transferred to the target catchment based on the "neighbouring" technic [21]. In our case, regional transfer is made by averaging parameters calibrated at the 3 closest neighbours from the ungauged target site.

\section{Reference flood quantiles}

The aim of the AIGA method is to inform about the rarity of on-going floods rather than provide absolute discharge estimates. In the initial AIGA method [18] discharges calculated in real time were compared with reference flood quantiles provided by the SHYREG method. The SHYREG method combines a punctual stochastic rainfall simulator and a rainfall-runoff model and is now recommended at the nationally for estimating reference flood quantiles at ungauged catchments [22].
Nevertheless, since long time series of gridded rainfall are now available and the hydrological models of the national version have been modified (compared to the SHYREG rainfall-runoff model), flood quantiles were generated from a continuous simulation of AIGA over the French territory for the 1998-2015 period (18 years). Reference flood quantiles were estimated by fitting a Gumbel law on the annual maximum values of the simulated streamflows.

\subsection{Evaluation methods}

The evaluation was made in two complementary ways: first, at gauged catchments for the whole 20022015 period using continuous measurements of discharge, and then at ungauged catchments using damage information for two specific events: the June2010 and October-2015 floods, both occurring in the South of France.

\section{Evaluation based on observed flows}

In this evaluation, the model is run continuously over the 2002-2015 period for all catchments (Fig. 2) and "events" are automatically defined whenever the daily catchment rainfall exceeds of $10 \mathrm{~mm}$ per day. This low threshold leads intentionally to a very large number of events. Then, since AIGA aims to issue a warning when the calculated flow exceeds a given return period, a contingency table is produced for all the events: for each "observed" and "calculated" flood event, we determine if the maximum discharge of the event (noted $Q p_{-} o b s$ and cal $Q p \_c a l$, respectively) exceeded or not a reference flood quantile of a given return period noted $\operatorname{Qobs}(T)$ and $Q \operatorname{cal}(T)$ respectively (Table 1$)$. Note that the $Q o b s(T)$ is derived from a statistical analysis carried out with observed flow, while $\operatorname{Qcal}(T)$ is generated from the same analysis, carried out on AIGA-estimated flows, in order to account for the AIGA model bias (see section 2.2).

\begin{tabular}{|c|c|c|c|}
\hline \multicolumn{2}{|c|}{ Event } & \multicolumn{2}{c|}{ Qp_obs $>$ Qobs $(T)$} \\
\cline { 3 - 4 } & Yes & No \\
\hline \multirow{2}{*}{$\begin{array}{c}\text { Qp_cal } \\
> \\
\text { Qcal }(T)\end{array}$} & \multirow{2}{*}{ Yes } & $\begin{array}{c}\text { Hit } \\
\text { (H) }\end{array}$ & $\begin{array}{c}\text { False Alert } \\
\text { (FA) }\end{array}$ \\
\cline { 2 - 4 } & No & $\begin{array}{c}\text { Miss } \\
\text { (M) }\end{array}$ & $\begin{array}{c}\text { True } \\
\text { Negative }\end{array}$ \\
\hline
\end{tabular}

Table 1. Contingency table for a given studied return period (ie: 2 year and 10 years)

Then, considering the number of hits $(\mathrm{H})$, miss $(\mathrm{M})$ and false alerts (FA) for all the events, the probability of detection (POD), success rate (SR) and critical success index (CSI) were calculated as follow:

$$
P O D=\frac{H}{H+M}
$$




$$
\begin{aligned}
& S R=\frac{H}{H+F A} \\
& C S I=\frac{H}{H+M+F A}
\end{aligned}
$$

These contingency scores were computed pooling together all the events of the different catchments from nine different French regions (assuming a relative performance homogeneity within a region), in order to have robust estimates (Fig. 3). Due to the length of available records (18 years), only two return periods were considered to compute the contingency scores: 2-year and 10-year thresholds, corresponding to a "common" flood and a relatively rare flood.

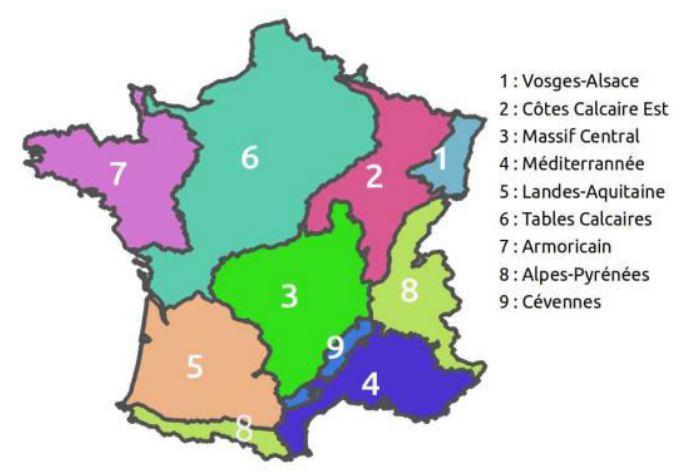

Figure 3. Regions used to calculate the contingency scores

\section{Evaluation based on damage reports}

The second evaluation concerns the "replay" of the AIGA warning system for two events: the 15-Jun-2010 flood near Draguignan, and the 03-Oct-2015 flood near Cannes. With 25 (+ 2 missing people) and 20 casualties respectively, these floods are in term of victims, the two most damaging floods since the September 2002 flood in the Gard department (23 deaths).

Considering their devastating impacts, numerous post-event surveys have been carried out for administrative and research purposes. For example, for both flood events, an HYMEX field campaigns (www.hymex.org) regrouping several French laboratories have collected hydrometeorological measurements and detailed information on impacts observed on the ground. As a result, these two events are particularly well documented in terms of impacts (numbers, localization, timing...), which enabled us to compare warnings issued by AIGA with impacts observed on the ground.

For the 15-Jun-2010 flood, information about casualties came from the Vict-In database elaborated by L. Boissier during his $\mathrm{PhD}$ [23], while damage information was compiled by Lefort and Koulinski [24]. For the 3-Oct-2015 flood, all the information was collected by C. Saint-Martin (on-going PhD). Various data sources were used, such as police reports, media, interviews, and social network.
AIGA discharges were simulated for all watersheds having an area ranging from $5 \mathrm{~km}^{2}$ to $3500 \mathrm{~km}^{2}$. Then, for each of them, we determined the timing of the 2 -year, 10 year and 50-year threshold exceedance. The simulation having being made at an hourly time step, calculated discharges were previously interpolate (linearly) at a 15min time step, in order to reproduce the 'real' operational method, which is up-dated every 15 minutes. Finally, the AIGA exceedance schedules were aggregated at a town level by taking for each return period (2-, 10- 50-year), the earlier exceedance observed in each town of the studied areas.

\section{Results}

\subsection{Evaluation using continuous measurements of discharges}

Results are summarised in table 2. Scores have been calculated separately for the nine regions by pooling together contingency statistics for all the stations within the region.

\begin{tabular}{|l|r|r|r|}
\hline Region & \multicolumn{1}{|c|}{ POD } & \multicolumn{1}{l|}{ SR } & \multicolumn{1}{l|}{ CSI } \\
\hline 1 & 0.42 & 0.47 & 0.29 \\
\hline 2 & 0.46 & 0.57 & 0.34 \\
\hline 3 & 0.58 & 0.56 & 0.40 \\
\hline 4 & 0.46 & 0.66 & 0.37 \\
\hline 5 & 0.71 & 0.62 & 0.50 \\
\hline 6 & 0.40 & 0.55 & 0.30 \\
\hline 7 & 0.45 & 0.71 & 0.38 \\
\hline 8 & 0.40 & 0.5 & 0.28 \\
\hline 9 & 0.77 & 0.67 & 0.56 \\
\hline Total & 0.48 & 0.59 & 0.36 \\
\hline
\end{tabular}

Table 2. Contingency score for threshold of 2-year return period threshold

Global results lead to a POD value of $48 \%$, a SR of $59 \%$ and a CSI of $36 \%$. At a regional scale, some differences can be observed: best results are obtained for the Cevennes region (9), where the POD, SR and CSI reach values of $77 \%, 67 \%$ and $56 \%$ respectively. Conversely, the region 8 (Alps and Pyrénées) obtain the worst score $(\mathrm{POD}=40 \%, \mathrm{SR}=50 \%$ and $\mathrm{CSI}=28 \%)$, Results for the 10-year flood quantile (not presented here) are slightly less satisfactory, with a similar pattern between the different regions.

Globally, these results indicate that the performances are much better in the regions from South of France $(9,5,3,4)$ and the Britanny (7). Conversely, the method seems to have more difficulties in the regions from the north of France $(1,2,6)$ and in mountainous areas (8). One explanation lies in the simplified parametrisation and structure of the conceptual model, rather built to reproduce fast floods, generated by runoff. 
For instance, snow melting processes neither the vertical soil water distribution is taken into account. Weak results in the Alps and Pyrénées (region 8) are also explained by the fact that the quality of the radar rainfall is less good in mountainous areas.

Given the calibration strategy to favour fast hydrological response to rainfall input and avoid missing flood events (see section 2.2), we expect the AIGA model to produce over-biased flows with simulated peak flows occurring earlier than the observed peak flow. Figure 4 illustrates this tendency with the following two examples: the Avière River at Frizon $\left(105 \mathrm{~km}^{2}\right)$ in the Vosges area (East of France) and the Lez at Montferrier-sur-Lez (115 $\mathrm{km}^{2}$ ) in the Herault area (South of France). On the right side of the Figure, are represented the raw observed and calculated hydrographs. Because a statistical law has been fitted on simulated discharges (see section 2.2), it is also possible to represent the evolution of the return period of the hydrograph (left side of figure 4). By construction, the 2-year, 10-year and 50-year reference quantiles calculated on observations and simulations coincide. This transformation procedure can be assimilated to a quantile-quantile correction procedure, widely used for instance in climate change modelling. In other words, calculating reference flood quantiles on simulations is the way to guaranty "un-biased" AIGA return-period estimations. It corrects the tendency of our model to over-estimate streamflows, while keeping a fast hydrological response.

\subsection{Evaluation results with damage reports}

In this section, we present the evaluation of the AIGA qualificatons based on damage reports for two case studies: the 15-June-2010 flood near Draguignan and the 3-October-2015 flood near Cannes. Two different aspects are considered: the spatial location of the AIGA qualifications, and their timing.

Figures 4 and 5 compare the AIGA maximal flow qualification during each event with the localisation of the casualties. In both case studies, almost all locations where casualties were reported contain at least one streamflow qualified by AIGA at its highest level (i.e. a 50 -year return period). One exception must be mentioned, the city of Frejus ( 2 casualties) during the 15Jun-2010 flood, with a 10-year return period flow qualification. These results indicate that the AIGA method efficiently identifies potentially impacted areas. Nevertheless, since AIGA does not take into account vulnerability and exposure factors, it provides information relative only to flood hazard. One promising current work (on-going $\mathrm{PhD}$, see [25] in this issue) is to combine the information provided by AIGA with social vulnerability and exposure factors in order to better identify impacts and produce spatial flood risk maps: depending on the local socioeconomic characteristics and recovery capacity, some areas and communities can be severely impacted for a relatively common flood, while others without any population or infrastructure exposed can stay undamaged even after a rare flood.

The timing of the AIGA flow qualifications is evaluated in Tables 3 and 4. When known, the hour of a given impact (damage or casualty) is compared to the first hour of the AIGA threshold exceedance (i.e. 2-year, 10 -year and 50-year quantiles) for the same town. For the 15-June-2010 flood, AIGA flow qualifications lead to early warnings for almost all the reported damages. Depending on the damage and the AIGA threshold considered, the lead times are around 1 hour to several hours. For the 3-October-2015 flood, results are different. Lead times are much more reduced, less than 1-hour.

These two contrasting results are explained by the differences between the two flood events. For the 15June-2010 flood was generated by intense rainfall over a relatively long time (for a flash flood): for instance Meteo-France measured $350 \mathrm{~mm}$ at Les Arcs over 9 hours, between $12 \mathrm{~h} 30$ and $21 \mathrm{~h} 30$. For the 3-October2015 , the intense rainfall lasted only two hours, with for instance $175 \mathrm{~mm}$ measured at Cannes between $20 \mathrm{~h}$ and $22 \mathrm{~h}$. Combined with the fact that this rainfall impacted small catchments, their response time was extremely short.

Nevertheless, even with a reduced lead time, the information given by AIGA seems useful, since it enables to have a synthetic view of the situation in real time. However, these results show the need to include precipitation forecasts, even if in the case of very convective event, large uncertainties are involved (see for instance [26] in this issue). 


\section{The Avière River at Frizon $\left(105 \mathrm{~km}^{2}\right)$}
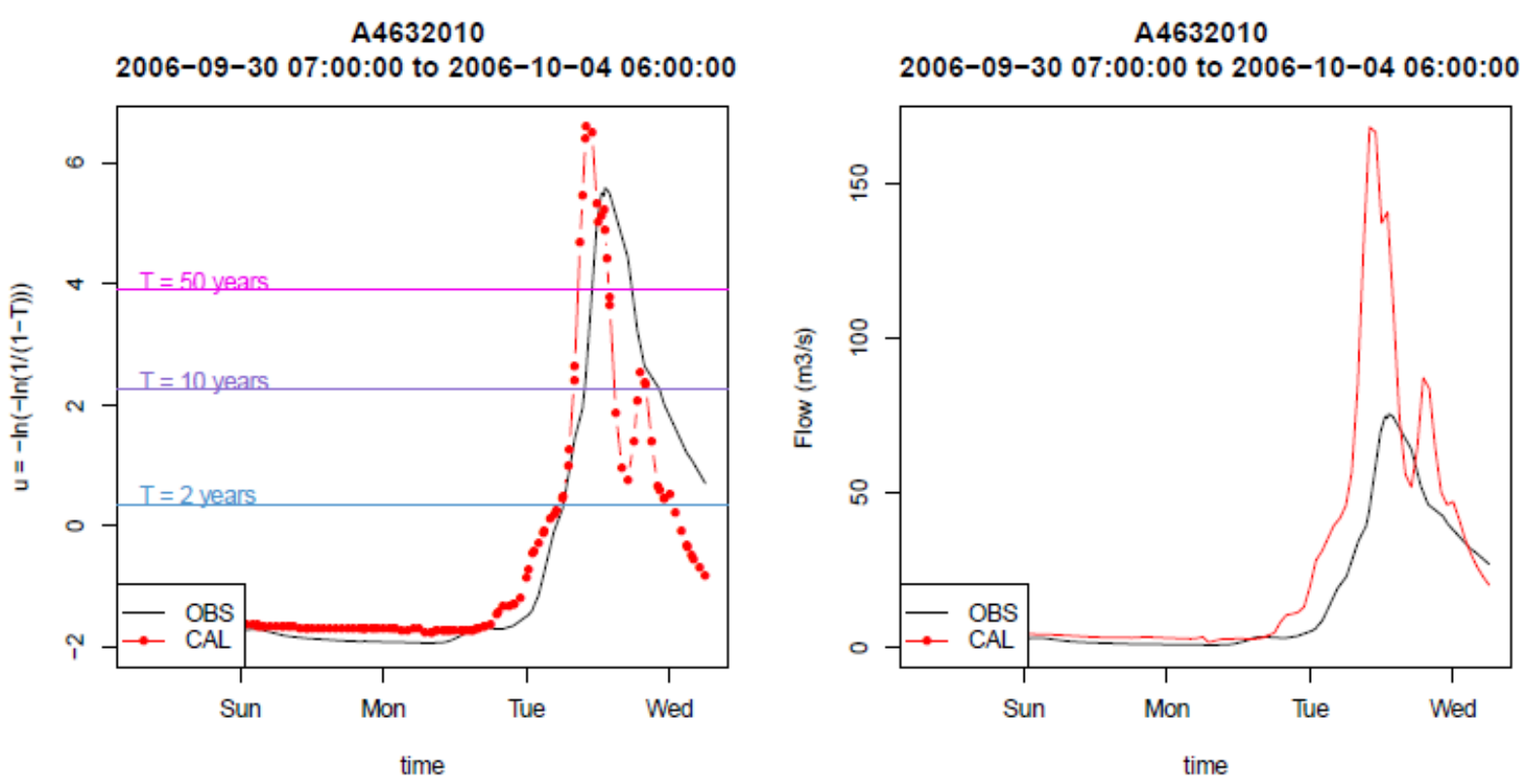

The Lez river at Montferrier-sur-Lez $\left(115 \mathrm{~km}^{2}\right)$
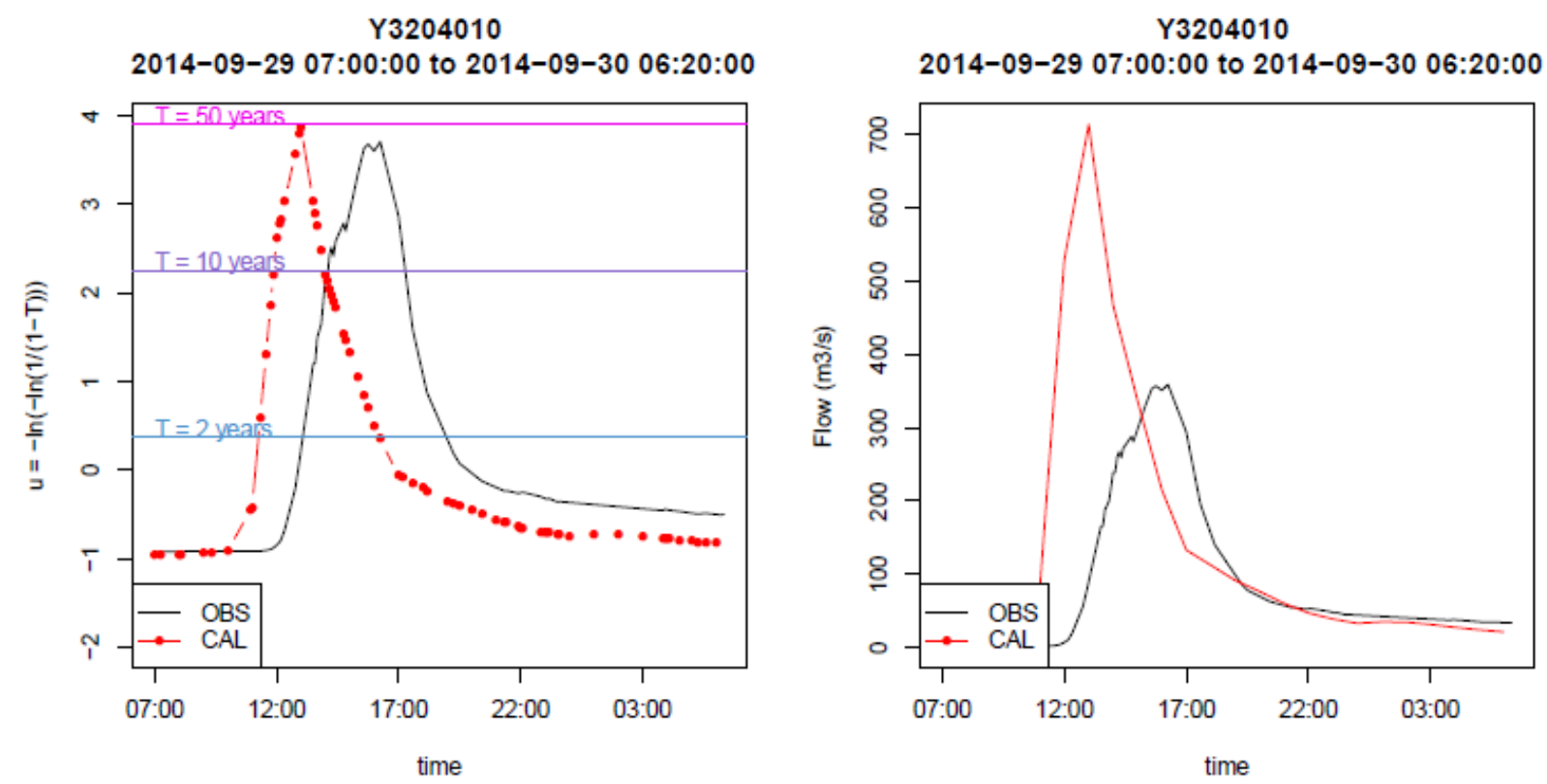

Figure 4. Example of simulated and observed hydrographs, with a quantile-quantile correction (left) and without (right) 


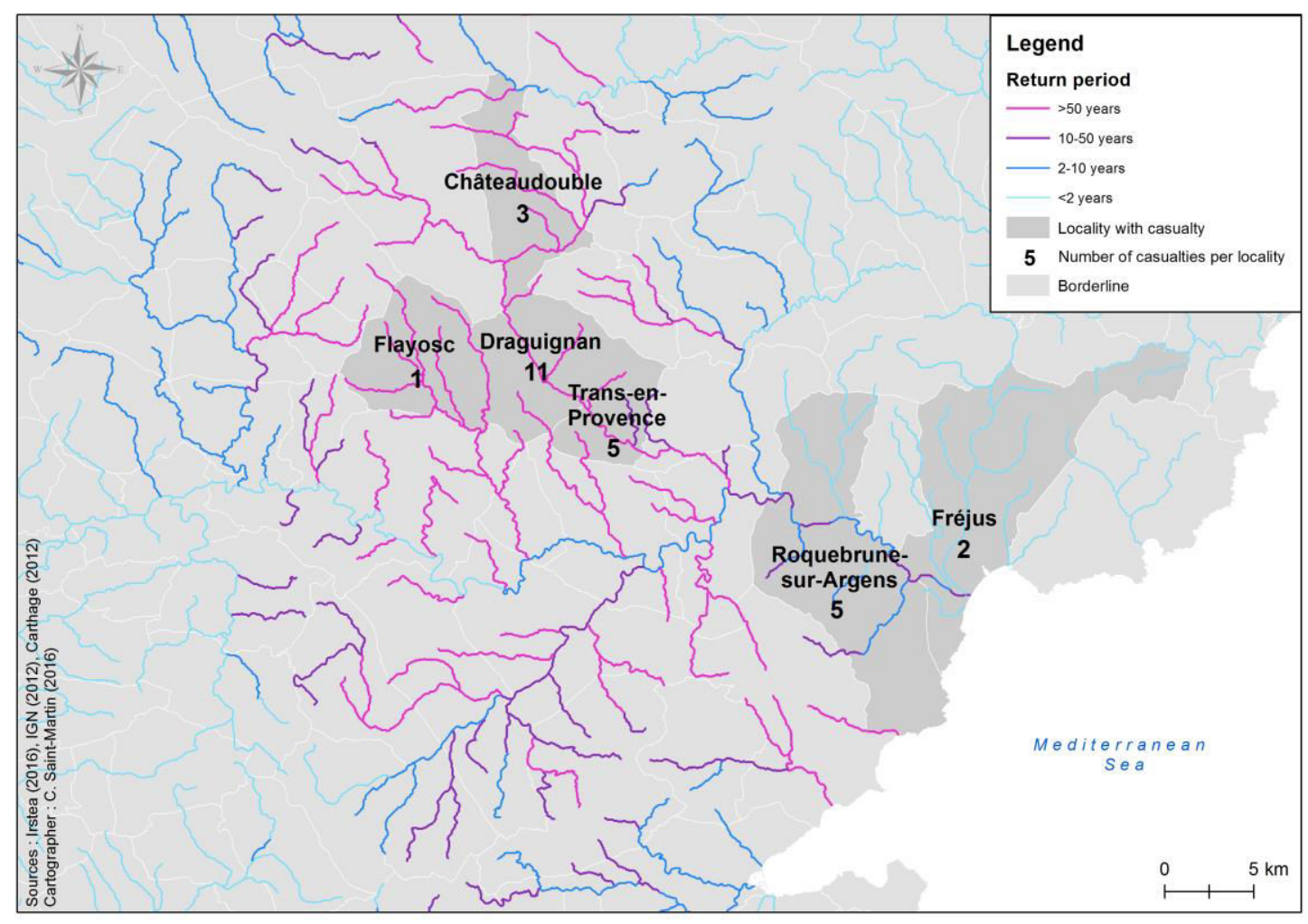

Figure 5. AIGA maximal qualification flow and localisation of the casualties for the 15-June-2010 flood

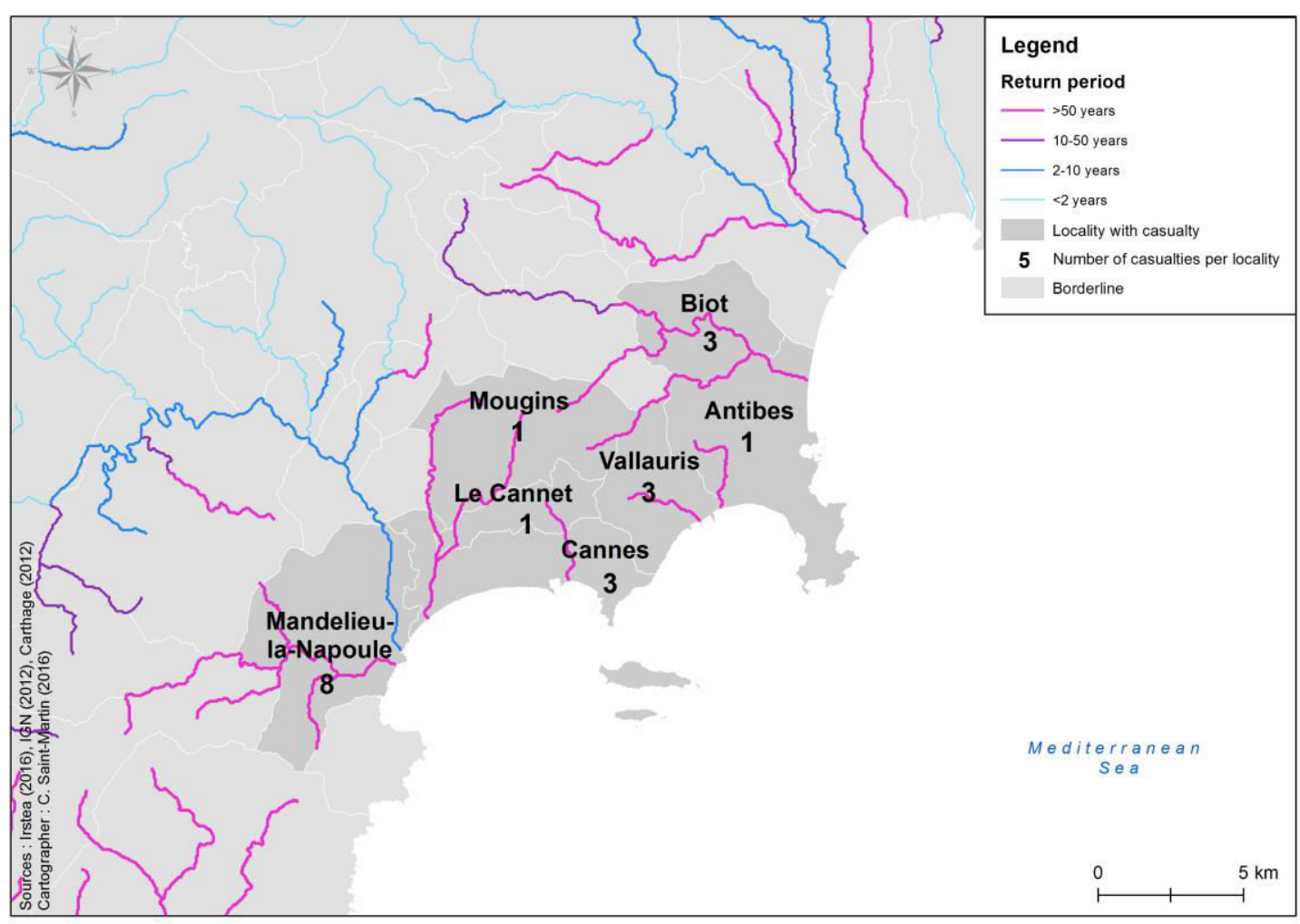

Figure 6. AIGA maximal qualification flow and localisation of the casualties for the 3-October-2015 flood 
FLOODrisk 2016 - $3^{\text {rd }}$ European Conference on Flood Risk Management

\begin{tabular}{|c|c|c|c|c|}
\hline \multirow{2}{*}{ Town } & \multirow{2}{*}{$\begin{array}{l}\text { Max. AIGA } \\
\text { qualification }\end{array}$} & \multicolumn{3}{|c|}{ Observed damage } \\
\hline & & hour & description & Source \\
\hline FLAYOSC & $\begin{array}{l}2-\mathrm{y} \text { at } 14 \mathrm{~h} 30 \\
10-\mathrm{y} \text { at } 15 \mathrm{~h} 00 \\
50-\mathrm{y} \text { at } 15 \mathrm{~h} 30\end{array}$ & $18 \mathrm{~h} 00$ & 1 casualty & police report \\
\hline LES ARCS & $\begin{array}{l}2-y \text { at } 14 \mathrm{~h} 30 \\
10-\mathrm{y} \text { at } 15 \mathrm{~h} 15 \\
50-\mathrm{y} \text { at } 15 \mathrm{~h} 30\end{array}$ & $\begin{array}{l}16 h 10 \\
16 h 40\end{array}$ & $\begin{array}{l}\text { First roads flooded } \\
\text { Collapse of main centre place (under which river was } \\
\text { canalised) }\end{array}$ & $\begin{array}{l}\text { Interviews } \\
\text { Interviews }\end{array}$ \\
\hline TARADEAU & $\begin{array}{l}2-\mathrm{y} \text { at } 14 \mathrm{~h} 45 \\
10-\mathrm{y} \text { at } 15 \mathrm{~h} 15 \\
50-\mathrm{y} \text { at } 15 \mathrm{~h} 30\end{array}$ & $16 \mathrm{~h} 00$ & $\begin{array}{l}\text { Bridge by-passed by the river (road access completely } \\
\text { destroyed) }\end{array}$ & Interviews \\
\hline $\begin{array}{l}\text { CHÂTEAU- } \\
\text { DOUBLE }\end{array}$ & $\begin{array}{l}2-\mathrm{y} \text { at } 14 \mathrm{~h} 45 \\
10-\mathrm{y} \text { at } 15 \mathrm{~h} 15 \\
50-\mathrm{y} \text { at } 15 \mathrm{~h} 30\end{array}$ & $\begin{array}{l}16 h 00 \\
17 h 50\end{array}$ & $\begin{array}{l}\text { Bridge overflooded, with } 1 \text { casualty } \\
\text { Hamlet of Rebouillon flooded, with } 2 \text { casualties }\end{array}$ & $\begin{array}{l}\text { police report } \\
\text { police report }\end{array}$ \\
\hline DRAGUIGNAN & $\begin{array}{l}2-y \text { at } 14 \mathrm{~h} 45 \\
10-\mathrm{y} \text { at } 15 \mathrm{~h} 15 \\
50-\mathrm{y} \text { at } 15 \mathrm{~h} 30\end{array}$ & $\begin{array}{c}17 \mathrm{~h} 00 \\
?\end{array}$ & $\begin{array}{l}\text { First roads flooded } \\
9 \text { casualties (afternoon and evening) }\end{array}$ & $\begin{array}{l}\text { Interviews } \\
\text { police report }\end{array}$ \\
\hline $\begin{array}{l}\text { TRANS-EN- } \\
\text { PROVENCE }\end{array}$ & $\begin{array}{l}2-y \text { at } 14 \mathrm{~h} 45 \\
10-\mathrm{y} \text { at } 15 \mathrm{~h} 15 \\
50-\mathrm{y} \text { at } 15 \mathrm{~h} 30\end{array}$ & $\begin{array}{c}17 \mathrm{~h} 45 \\
?\end{array}$ & $\begin{array}{l}\text { First roads flooded } \\
5 \text { casualties (end of afternoon, evening and night) }\end{array}$ & $\begin{array}{l}\text { Interviews } \\
\text { police report }\end{array}$ \\
\hline LE MUY & $\begin{array}{l}2-\mathrm{y} \text { at } 15 \mathrm{~h} 15 \\
10-\mathrm{y} \text { at } 15 \mathrm{~h} 45 \\
50-\mathrm{y} \text { at } 16 \mathrm{~h} 00\end{array}$ & $20 \mathrm{~h} 30$ & A8 motorway flooded & Interviews \\
\hline LE LUC & $\begin{array}{l}2-\mathrm{y} \text { at } 14 \mathrm{~h} 00 \\
10-\mathrm{y} \text { at } 16 \mathrm{~h} 45 \\
50-\mathrm{y} \text { at } 17 \mathrm{~h} 00\end{array}$ & $17 \mathrm{~h} 40$ & 1 casualty & police report \\
\hline $\begin{array}{l}\text { ROQUEBRUNE- } \\
\text { SUR-ARGENS }\end{array}$ & $\begin{array}{l}2-\mathrm{y} \text { at } 16 \mathrm{~h} 00 \\
10-\mathrm{y} \text { at } 17 \mathrm{~h} 15 \\
50-\mathrm{y} \text { at } 22 \mathrm{~h}\end{array}$ & $\begin{array}{l}22 \mathrm{~h} 00 \\
22 \mathrm{~h} 15 \\
22 \mathrm{~h} 30 \\
00 \mathrm{~h} 00 \\
00 \mathrm{~h} 15 \\
01 \mathrm{~h} 00\end{array}$ & $\begin{array}{l}\text { Bridge by-passed ( } 20 \text { people blocked on it) } \\
2 \text { casualties } \\
1 \text { casualty } \\
1 \text { casualty } \\
\text { Flooding in town } \\
1 \text { casualty }\end{array}$ & $\begin{array}{l}\text { Interviews } \\
\text { police report } \\
\text { police report } \\
\text { police report } \\
\text { Interviews } \\
\text { police report }\end{array}$ \\
\hline FREJUS & $\begin{array}{l}2-\mathrm{y} \text { at } 16 \mathrm{~h} 00 \\
10-\mathrm{y} \text { at } 18 \mathrm{~h} 00 \\
50-\mathrm{y}: \text { not } \\
\text { exceeded }\end{array}$ & $\begin{array}{c}\text { 03h15 } \\
?\end{array}$ & $\begin{array}{l}\text { Flooding in town, campsites evacuated } \\
2 \text { casualties (night) }\end{array}$ & $\begin{array}{l}\text { Interviews } \\
\text { police report }\end{array}$ \\
\hline
\end{tabular}

Table 3. Damage reports for the June-2010 flood event

\begin{tabular}{|c|c|c|c|c|}
\hline \multirow{2}{*}{ Town } & \multirow{2}{*}{$\begin{array}{l}\text { Max. AIGA } \\
\text { qualification }\end{array}$} & \multicolumn{3}{|c|}{ Observed damage } \\
\hline & & hour & description & Source \\
\hline $\begin{array}{l}\text { MANDELIEU-LA- } \\
\text { NAPOULE }\end{array}$ & $\begin{array}{l}2-y \text { at } 20 h 15 \\
10-y \text { at } 20 h 30 \\
50-y \text { at } 20 h 45\end{array}$ & $\begin{array}{c}21 \mathrm{~h} 00 \\
21 \mathrm{~h} 30 \\
21 \mathrm{~h} 30 \\
?\end{array}$ & $\begin{array}{l}\text { A8 motorway flooed (traffic stopped) } \\
\text { Campsite flooded } \\
\text { Houses flooded } \\
8 \text { casualties, in } 2 \text { underground flooded car parks (exact time } \\
\text { not known, but ranging from } 20 \mathrm{~h} \text { to } 22 \mathrm{~h} \text { ) }\end{array}$ & $\begin{array}{l}\text { VinciAutoroute } \\
\text { Interview } \\
\text { Interview } \\
\text { Media }\end{array}$ \\
\hline CANNES & $\begin{array}{l}2-y \text { at } 20 h 15 \\
10-y \text { at } 20 h 30 \\
50-y \text { at } 20 h 30\end{array}$ & $\begin{array}{l}21 \mathrm{~h} 00 \\
21 \mathrm{~h} 30 \\
21 \mathrm{~h} 30 \\
22 \mathrm{~h} 20 \\
? \\
?\end{array}$ & $\begin{array}{l}\text { First report of a flooded (sport room) } \\
\text { Many reports on flooded buildings } \\
\text { Movie theather flooded and evacuated } \\
1 \text { casualty } \\
1 \text { casualty (evening) } \\
1 \text { casualty (next morning, in a cellar) } \\
\end{array}$ & $\begin{array}{l}\text { Media } \\
\text { Interviews } \\
\text { Witness via twitter } \\
\text { Media } \\
\text { Media } \\
\text { Media }\end{array}$ \\
\hline BIOT & $\begin{array}{l}2-y \text { at } 20 h 15 \\
10-y \text { at } 20 h 30 \\
50-y \text { at } 20 h 45\end{array}$ & $\begin{array}{l}21 \mathrm{~h} 00 \\
22 \mathrm{~h} 00 \\
22 \mathrm{~h} 30\end{array}$ & $\begin{array}{l}3 \text { casualties in a flooded retirement home } \\
\text { Many flooded buildings: houses, small factories, shops... } \\
\text { Campsite flooded }\end{array}$ & $\begin{array}{l}\text { Media } \\
\text { Interviews } \\
\text { Media }\end{array}$ \\
\hline ANTIBES & $\begin{array}{l}2-y \text { at } 20 h 15 \\
10-y \text { at } 20 h 30 \\
50-y \text { at } 20 h 45\end{array}$ & $\begin{array}{c}21 \mathrm{~h} 20 \\
?\end{array}$ & $\begin{array}{l}\text { A8 motor way flooded (traffic stopped) } \\
1 \text { casualty }\end{array}$ & $\begin{array}{l}\text { VinciAutoroute } \\
\text { Media }\end{array}$ \\
\hline $\begin{array}{l}\text { VILLENEUVE- } \\
\text { LOUBET }\end{array}$ & $\begin{array}{l}2-\mathrm{y} \text { at } 20 \mathrm{~h} 30 \\
10-\mathrm{y} \text { at } 21 \mathrm{~h} 15 \\
50-\mathrm{y} \text { at } 21 \mathrm{~h} 45\end{array}$ & $23 \mathrm{~h} 00$ & Campsite flooded & Media \\
\hline
\end{tabular}

Table 4. Damage reports for the October-2015 flood event 


\section{Discussion and conclusion}

For the national implementation of the warning system, the semi-distributed hydrological model of the AIGA method has been enhanced to include a baseflow estimation module. The calibration and regionalisation of the model parameters were carried out on $\sim 700$ catchments, fixing a number of parameters while maintaining satisfactory performance. The small capacity of the global routing store was chosen to favour fast hydrological response to rainfall input to avoid missed flood warnings. The potential bias of AIGA simulated flows was taken into account by using flood quantiles estimated from long-term AIGA simulations. The resulting spatial information of the flood situation describes the potential severity of ongoing and upcoming event at any point along the river network, while only partial and local information would generally emerge from the impacted areas, sometimes hindered by communication problems (e.g. lost mobile network for the June 2010 event). The performance of the warning system was analysed by comparing, first, the AIGAsimulated flood threshold exceedances with observed floods using continuous simulated and observed time series on all study catchments, and then, by comparing the AIGA flow qualifications to damage reports for 2 severe flood events in the South-East of France.

The evaluation yielded the following results:

- the contingency scores for the 2-year and 10-year flood quantiles showed satisfactory results with significant regional disparity though; this could be explained by the simplicity of the hydrological modelling approach (e.g., with no snow modelling) and by errors in the radar-gauge rainfall grids (e.g. in mountaneous areas) and flow measurements, especially during high flow events due to malfunctioning gauges;

- AIGA flood qualifications were coherent with the impacts observed on the ground, even if the effective warning lead time or flood anticipation was limited to catchments with longer response time; for the October 2015 event, early detection of flooding was especially challenging due to the intense and very localised rainfall event, and the fast response time of the impacted catchments; also the warning system should account for societal vulnerability factors and the dynamic nature of population exposure to fast evolving events to provide appropriate flood risk information. This emphasizes the need to develop comprehensive observational and postevent damage database to determine decision-relevant thresholds for the warning system.

In order to improve the AIGA-based warning system, ongoing research focuses on the hydrological model enhancements, the use of precipitation forecasts and nowcast products to increase the warning anticipation (see for instance [26] in this issue), the quantification of the main sources of uncertainty (e.g., precipitation ensemble forecasts as well as radar-gauge ensembles), and the integration of vulnerability information to communicate appropriate flood risk warnings to a wide range of users, from small communities to large urban areas (see [25] in this issue).

Other important issues to be discussed are to define the practical modalities for issuing the future warnings. Which AIGA qualifications should be selected? Which municipalities will be covered? What should be the link with other current warning systems (i.e., the APIC warnings issued by Meteo-France for intense rainfall or the "vigilance" systems)? A steering comittee, led by the SCHAPI, and involving Meteo-France, Irstea and future end-users currenlty works on these issues. The future service will be fully operational in 2017 [27].

\section{References}

1. Creutin, J.D. and M. Borga, Radar hydrology modifies the monitoring of flash-flood hazard. Hydrological Processes, 2003. 17(7): p. 14531456.

2. Borga, M., et al., Hydrogeomorphic response to extreme rainfall in headwater systems: Flash floods and debris flows. Journal of Hydrology, 2014. 518, Part B(0): p. 194-205.

3. Rouzeau, P., Martin, X., Pauc, J-C., Retour d'expérience des inondations survenues dans le département du Var les 15 et 16 juin 2010, 2010, Inspection générale de l'administration, Ministère de l'écologie, de l'energie, du développement durable et de la mer, Ministère de l'intérieur, de l'outre mer et des collectivités territoriales. p. 87.

4. Ruin, I., et al., Social and Hydrological Responses to Extreme Precipitations: An Interdisciplinary Strategy for Postflood Investigation. Weather, Climate, and Society, 2014. 6(1): p. 135-153.

5. environment, F.m.o., Plan submersions rapide : submersions marines, crues soudaines et ruptures de digues. http://www.developpementdurable.gouv.fr/IMG/pdf/Le plan_submersion_r apide.pdf, 2011. p. 80.

6. Moore, R.J., V.A. Bell, and D.A. Jones, Forecasting for flood warning. Comptes Rendus - Geoscience, 2005. 337(1-2): p. 203-217.

7. Reed, S., J. Schaake, and Z. Zhang, A distributed hydrologic model and threshold frequencybased method for flash flood forecasting at ungauged locations. Journal of Hydrology, 2007. 337(3-4): p. 402-420.

8. Cole, S.J. and R.J. Moore, Distributed hydrological modelling using weather radar in gauged and ungauged basins. Advances in Water Resources, 2009. 32(7): p. 1107-1120.

9. Younis, J., S. Anquetin, and J. Thielen, The benefit of high-resolution operational weather forecasts for flash flood warning. Hydrology and 
Earth System Sciences, 2008. 12(4): p. 10391051.

10. Alfieri, L., J. Thielen, and F. Pappenberger, Ensemble hydro-meteorological simulation for flash flood early detection in southern Switzerland. Journal of hydrology, 2012. 424 425(1): p. 143-153.

11. Braud, I., et al., The use of distributed hydrological models for the Gard 2002 flash flood event: Analysis of associated hydrological processes. Journal of Hydrology, 2010. 394(12): p. 162-181.

12. Georgakakos, K.P., Analytical results for operational flash flood guidance. Journal of Hydrology, 2006. 317(1-2): p. 81-103.

13. Ntelekos, A.A., K.P. Georgakakos, and W.F. Krajewski, On the uncertainties of flash flood guidance: Toward probabilistic forecasting of flash floods. Journal of Hydrometeorology, 2006. 7(5): p. 896-915.

14. Alfieri, L., D. Velasco, and J. Thielen, Flash flood detection through a multi-stage probabilistic warning system for heavy precipitation events. Adv. Geosci., 2011. 29: p. 69-75.

15. Alfieri, L. and J. Thielen, A European precipitation index for extreme rain-storm and flash flood early warning. Meteorological Applications, 2015. 22(1): p. 3-13.

16. Alfieri, L., et al., Operational early warning systems for water-related hazards in Europe. Environmental Science and Policy, 2012. 21: p. 35-49.

17. Raynaud, D., et al., A dynamic runoff coefficient to improve flash flood early warning in Europe: evaluation on the 2013 central European floods in Germany. Meteorological Applications, 2015. 22(3): p. 410-418.

18. Javelle, P., et al., Evaluating flash-flood warnings at ungauged locations using post-event surveys: a case study with the AIGA warning system. Hydrological Sciences Journal-Journal Des Sciences Hydrologiques, 2014. 59(7): p. 1390-1402.

19. Lavabre, J. and Y. Gregoris. AIGA: A flood forecasting tool. Application to the French Mediterranean region. in Water Resource Variability : analyses and impacts. FRIEND 2006. 2006. La Havane (Cuba): AISH Publications.

20. Perrin, C., C. Michel, and V. Andréassian, Improvement of a parsimonious model for streamflow simulation. Journal of Hydrology, 2003. 279(1-4): p. 275-289.

21. Oudin, L., et al., Spatial proximity, physical similarity, regression and ungaged catchments: A comparison of regionalization approaches based on 913 French catchments. Water Resources Research, 2008. 44(3).

22. Organde, D., et al., Régionalisation d'une méthode de prédétermination de crue sur l'ensemble du territoire français : la méthode
SHYREG. Revue des sciences de l'eau, 2013. 26(1): p. 65-78.

23. Boissier, L., La mortalité liée aux crues torrentielles dans le Sud de la France: une approche de la vulnérabilité humaine face à l'inondation, 2013, Université Paul Valéry Montpellier III.

24. Lefort, P., Koulinski, V., Crue du 15-16 juin 2010: Expertise post-crue, Tome 1, Analyse hydrologique de la crue de juin 2010. Conseil Général du Var, Direction de l'Environnement, Service Rivière et Milieux Aquatiques, Syndicat intercommunal d'Aménagement de la Nartuby, 2011: p. 33.

25. Saint-Martin, C., et al. Assessing the exposure to flooding to implement an flood impact model for French Mediterranean basins. in FLOODrisk 2016 - 3rd European Conference on Flood Risk Management. 2016. Lyon - France.

26. Caseri, A., et al. A space-time geostatistical approach for ensemble rainfall nowcasting. in FLOODrisk 2016 - 3rd European Conference on Flood Risk Management. 2016. Lyon - France.

27. de Saint-Aubin, C. et al. A new French flash flood warning service in FLOODrisk 2016 - 3rd European Conference on Flood Risk Management. 2016. Lyon - France. 